\title{
John Irvine Hunter (1898-1924): Australian Anatomist and Medical Educator
}

\author{
Sean Barrett ${ }^{1}$, Goran Štrkalj² \\ ${ }^{1}$ Department of Medical Imaging, The Canberra Hospital, Canberra, Australia, ${ }^{2}$ Department of Anatomy, Faculty of Medicine, \\ University of New South Wales, Sydney, Australia
}

Correspondence: g.strkalj@unsw.edu.au; Tel.: + 6129385 6837; Fax.: + 61293856369

Received: 10 April 2020; Accepted: 21 April 2020

\begin{abstract}
This paper focuses on the short, but brilliant career of the Australian anatomist and medical educator, John Irvine Hunter. Hunter's biography is presented within the context of the early twentieth century anatomy and medical education. John Irvine Hunter was not only the youngest ever Professor of Anatomy at the University of Sydney, but he was also undeniably brilliant with regard to teaching and researching anatomy, physiology and anthropology. While his short career answered many questions in these fields, it raised more questions regarding what Hunter may have accomplished if only he had been given the chance. These unanswered questions have spawned what we now affectionately refer to as the "Hunter Legend". His most ambitious work on the dual innervation of striated muscle, while eventually disproven, formed an important stepping-stone in the bridging of anatomy and physiology. His thought-provoking concepts were viewed with much intrigue, and at the time were very well received. Conclusion. Hunter remains one of the most prominent and inspiring figures in the history of Australian anatomy and medicine.
\end{abstract}

Key Words: John Irvine Hunter • Anatomy • Medical Education • University of Sydney • Australia.

\section{Introduction}

It is uncommon that an individual is prolific to the level of referring to their life as a "Legend", but that is precisely what John Irvine Hunter achieved in his short 26 years. Undeniably brilliant, and loved universally by his students and colleagues, he amassed an impressive research portfolio and gained a reputation as an excellent teacher and a wonderful friend. His first name and surname, shared with the famous Scottish surgeon/anatomist John Hunter (1728-1793), seemed to have "predestined" him for a career in anatomy and medicine. Indeed, he will be remembered for bridging the gap between anatomy and physiology, as well as heading one of the most important departments at a pioneering Australian medical school.

What is less well known of Hunter, and perhaps a driving force behind the development of the "Hunter Legend", is the important role that he played in a complex social climate in aftermath of World War I. His mentors obviously saw something in Hunter that was needed in a turbulent time not only for the medical profession, but also to generate optimism and restore faith in the public. His astronomical rise was met with mostly praise, but also with criticism. By the time of Hunter's death, he was a treasured teacher, researcher and human being who served his role with immense passion and pride. Hunter rightly forged his legend, and firmly established himself as one of the great anatomical minds of his time.

This paper explores the life, academic career and untimely death of Professor John Irvine Hunter, and will provide a snapshot of the world of medical anatomy and research in the early 20th century.

\section{Early Life}

John Irvine Hunter (Figure 1) was born 24 January 1898 in Bendigo, a town in Australia's state of 
Victoria, where his father originally worked as a gold digger and later a furniture salesman. John Hunter, oras his family lovingly called him "Jack", had a tumultuous upbringing, at least in part due to a protracted course of treatment for his bilateral clubfoot deformity. It was through this chronic and ongoing condition that he likely developed the patience and persistence that later formed the cornerstone of his academic prowess (1). His family were not wealthy, and they were often afforded concessions for the expensive treatment of his clubfoot deformity that he received from Dr W. L. Long, a local surgeon in Bendigo. His treatment was ultimately successful and afforded him the ability to play numerous sports and resume most of the typical childhood activities. Hunter later reflected back on these experiences, and wrote to Dr Long, thanking him for his generosity $(1,2)$.

At around the age of eleven, he was again struck down by illness that was characterised by pleurisy and blood-stained sputum, which some believe may have been pulmonary tuberculosis. Around the same time, his parents' marriage broke down, and he was sent to live with his mother's sister and her husband in Albury, New South Wales, Australia.

Hunter attended Albury Superior Public School and excelled academically. He excelled so much so that his Latin teacher and headmaster pushed for his admission at the highly regarded Fort Street High School. He was accepted to Fort Street and again, he excelled. From his time at Fort Street he was known not only for his academic and intellectual excellence, but also for his charming disposition (1). Even from an early age, Hunter demonstrated an innate ability to teach and educate his peers and was known for his ability to convey complex ideas in an understandable manner for his fellow students. This innate ability was again observed in medical school when he was noted to fill up entire halls to teach anatomy to his peers, many of which were senior to him. His headmaster at Fort Street later afforded that many people "never realised that he was such an incomparable genius". This "genius" as many suggested, was probably masked or perhaps overlooked by the physical and economic hardship that he endured as a child $(3,4)$.

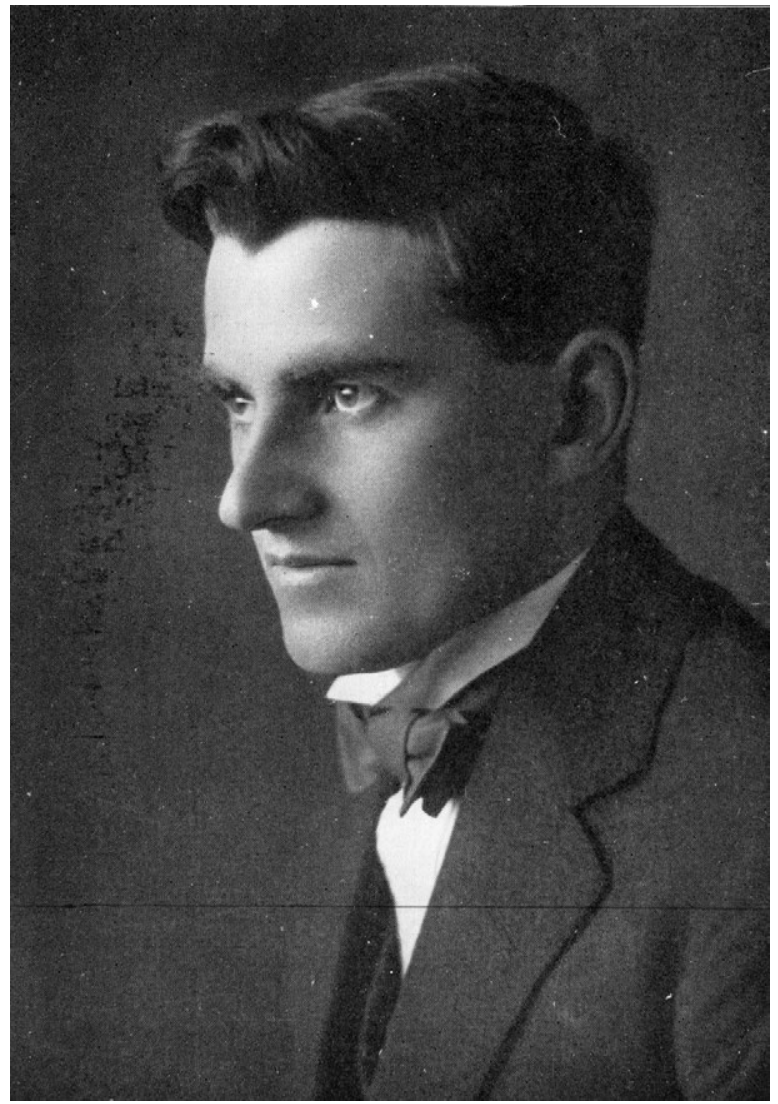

Figure 1. John Irvine Hunter in 1920 (courtesy of the University of Sydney Archives).

Upon completion of his time at Fort Street, he was able to gain entry to study medicine at the University of Sydney. After some period of uncertainty as to whether this would be financially feasible, he was ultimately able to secure a bursary that would cover his course fees and contribute a small amount towards his living expenses (3). Fortunately, his uncle was able to provide additional financial security to ensure that Hunter was able to study medicine, which he commenced in 1915.

\section{Medical School}

Hunter commenced his studies during a turbulent time, not only for the medical profession but for Australia and many other parts of the world generally, as this was during the height of World War I. The founder of the medical school at the University of Sydney, Sir Thomas Anderson Stu- 
art, had argued strongly against medical students enlisting in the defence forces prior to completion of their studies. Conversely, the Challis Professor (an eponymous professorship at the University of Sydney, honoring the nineteenth century philanthropist and University's benefactor John Henry Challis) of Anatomy at the time, and future great friend of Hunter's, James Thomas Wilson, had instead argued that the medical students should be enlisting (1).

Hunter, in 1916, enlisted in the forces, along with many of his colleagues, and after farewelling his loved ones and preparing to commence training, he actually received an official notice ordering him to return to his studies. It much later emerged that it was in fact Wilson who had contradicted his earlier encouragement towards his students to enlist and had instead ordered for Hunter to resume his studies. Wilson had observed, even in those early stages, something exceptional in Hunter, and had decided that this level of brilliance should be instead nurtured. The interest that Wilson had taken in the young Hunter is of particular importance, not only because he interrupted Hunter's plans of enlisting in the defence forces, but because it was Wilson who revitalised the department of anatomy at the University of Sydney. He did this in a number of ways, namely by reclaiming histology from the physiologists and incorporating histology into the teaching of anatomy, but also by laying the groundwork to facilitate Hunter's meteoric rise through the ranks of the university only a few years later. Perhaps the latter aspect of Wilson's plan for the university was based on the tumultuous social climate that was apparent in the aftermath of World War I and believed that by placing some faith in the youthful genius of Hunter, perhaps that could help to reinvigorate and promote optimism in society once again.

During his time at university, he rapidly became a source of anatomical knowledge for his colleagues, even those far more senior than him. He was required to run his anatomy tutorials off campus at the Darlington Town Hall, as the conventional lecture theatres at the University of Syd- ney were not big enough to accommodate the students attending his lectures (1)! The notes that he wrote for his review of neuroanatomy were reproduced and given to all students as a core text. $\mathrm{He}$ obtained the highly prized role of prosector in just his second year of university, and he was highly regarded by his colleagues both as an excellent medical student, but also as an excellent human being.

Just as he succeeded in his secondary schooling, Hunter again demonstrated his academic excellence at university level, winning all major awards in his degree, aside from in his first year of study. In his final year of medical school, he won the Sandes prize for best surgical essay, a considerably large paper on visceral abdominal pain, that was later published in the Medical Journal of Australia (5). In addition to this, he also graduated with first class honours and claimed the university medal in medicine.

\section{Professorship and Overseas Travel}

After graduating with a Bachelor of Medicine, Bachelor of Surgery degree in 1920, Hunter had the difficult choice of pursuing a career in academia or clinical medicine. It is likely that he would have succeeded regardless of what option he ultimately chose, having demonstrated an innate ability in clinical work as well as in academic roles. Ultimately though, he decided to pursue a career in anatomy, and immediately following his graduation he was appointed as an anatomy demonstrator at the University of Sydney (Figure 2).

The duties of demonstrators, at the time, were similar to those of the tutors/demonstrators in contemporary Australian Medical Schools and comprised assistance in practical instructions and dissections carried out in the anatomy laboratory. Hunter was renowned by his students and colleagues as being a brilliant teacher, and again demonstrated his innate ability to convey complex information in an approachable manner $(1,2)$.

His role as a demonstrator, however, was short lived. Challis Professor of Anatomy, James Thomas Wilson, resigned the very same year, and moved to Britain to take the Chair of Anatomy at the Uni- 


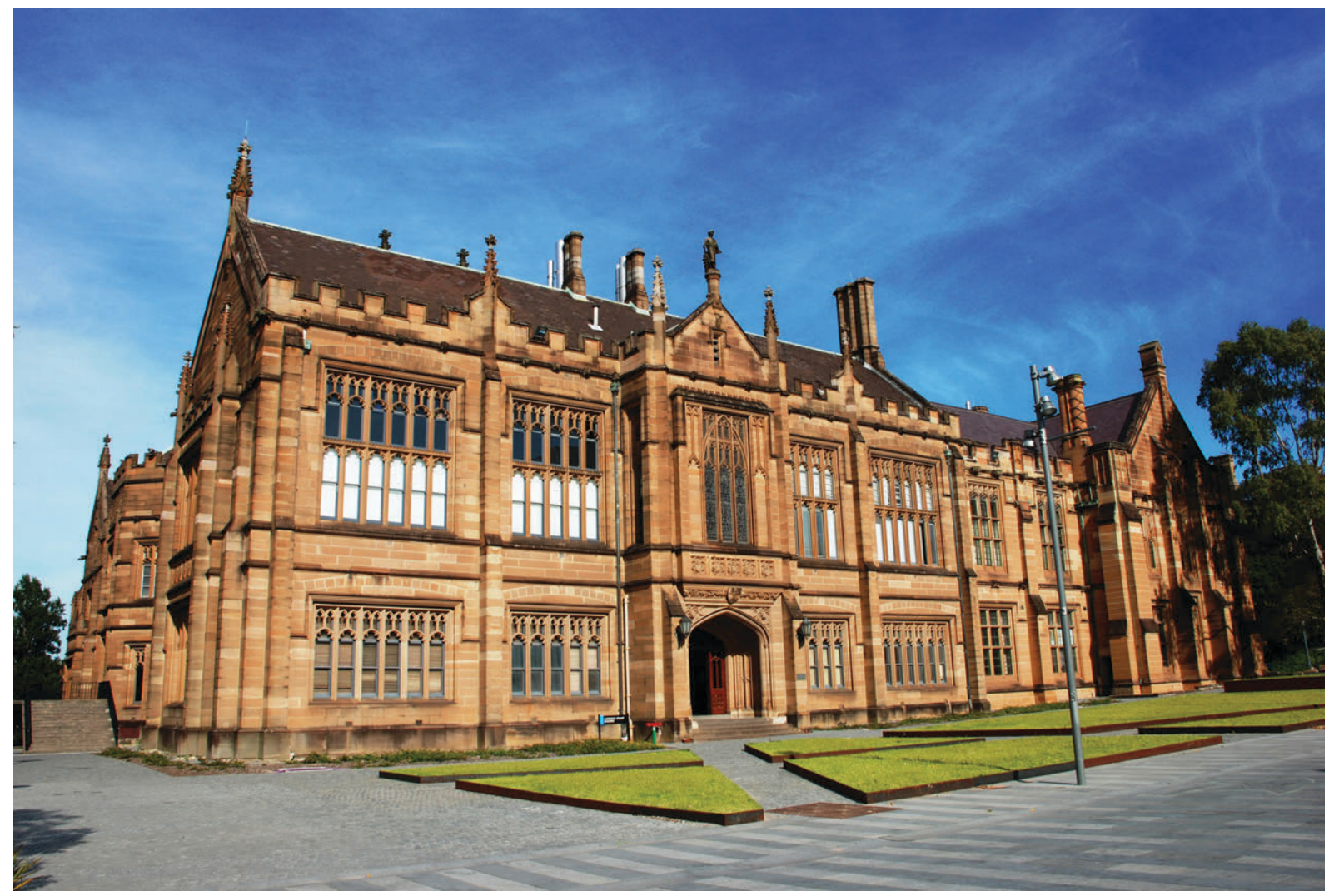

Figure 2. The Anderson Stuart Building (formerly known as the "Old Medical School") at the University of Sydney, where the Department of Anatomy has been located (photograph by Sumple, licensed under CC BY-SA).

versity of Cambridge (6). As a result of Wilson's resignation and his desire to see Hunter promoted at the university, Hunter was appointed as Associate Professor of Anatomy. His astronomical rise through the ranks of the university was met with both positivity from his colleagues and negativity from those who did not know him. The Sydney Morning Herald was particularly critical, using Hunter's appointment as a catalyst to suggest that the university had lost touch with the citizens of New South Wales and claimed that the University of Sydney would "sink back into its peaceful obscurity” (1). As previously mentioned, Wilson's ambitious and optimistic promotion of Hunter was perhaps a reflection of the social climate and the need for change. Despite initially being met with criticism, Hunter's promotion was ultimately praised universally.

In 1921, Hunter was granted one year's leave on full pay to travel overseas and continue his studies, primarily basing himself in London and travelling throughout Europe. Prior to leaving Australia, he became very interested in the work of orthopaedic surgeon Dr Norman Royle, who would later become both a close friend and research associate of Hunter's. In this one-year period overseas, Hunter was able to further his studies of anatomy, physiology and anthropology, as well as gain important life experience, that was later reflected in his correspondence with his aunt (1).

With his close friend and fellow anatomist and anthropologist, Grafton Elliot Smith, Hunter studied the famous Piltdown Man fossil in East Sussex, and while ultimately incorrect, they contributed to the growing body of research that this specimen generated (7). They believed that the skull of the Piltdown Man did indeed represent a "missing link" in human evolution, due to an abnormal mandible and the relatively small cranial fossa. However, it was later determined that the Piltdown 
remains from which these hypotheses were generated was an artificially produced chimera, made up of both orangutan and human bones. It was not until much later that the Piltdown Man hoax was adequately exposed (8).

Hunter's association with Smith was no coincidence, with Smith being a student and somewhat of a protégé of Wilson's at the University of Sydney. Smith was another of those students that had been identified as exemplary at an early stage in their career and had been assisted by Wilson to reach their full potential. Smith was essentially the embodiment of British anatomy and revolutionised the teaching and study anatomy when he was appointed chair of anatomy at University College, London $(9,10)$. After the World War I Smith became one of the key architects of "the new British anatomy project", which enlivened the discipline of anatomy by reincorporating "physiology and other allied disciplines, whilst continuing to maintain gross anatomy at the centre" (10). None of this revolutionary work by Smith would have been possible without the very large amount of financial support bestowed upon him by the Rockefeller Foundation. Wilson's ability to identify future leaders (such as Smith) and nurture them was seemingly passed onto Smith, who dispatched his trainees around the world, and in 1938 around 20 of his former trainees held chairs of anatomy around the world. They introduced Smith's "holistic" philosophy to Medical School across the globe and established numerous centers of teaching and research excellence (11). Once again, the fact that both Wilson and Smith had taken a particularly close interest in Hunter begs the question of what Hunter would have become if he had not met his untimely demise.

When in London, Hunter had also been closely following the research of Professor Nicholai Konstantinovich Kulchitsky (who discovered enterochromaffin or Kulchitsky cells), particularly that of his work on innervation of striated muscle (12). As chance would have it, Kulchitsky, a Russian refugee, had recently commenced working at University College in London, alongside Grafton Elliot Smith, and as such, Hunter was able to form a close personal and working relationship (1). Kulchitsky's initial research demonstrated two nerve fibre variants that were involved in the innervation of striated muscle, and this formed a major component of Hunter's most ambitious work that he later undertook, which was received with much curiosity and intrigue at the time.

Hunter also visited and worked in various centres of excellence in the continental Europe. While on the Continent Hunter worked with renowned Dutch neurologist and anatomist Ariëns Kappers. Under Kappers he carried out research on the Kiwi brain, which formed part of the work in neuroanatomy for which he would be awarded his Doctor of Medicine degree from the University of Sydney, in 1924 (13). Hunter returned to Australia in 1923 and assumed the role of Challis Professor of Anatomy at the University of Sydney. It was then that he resumed his close collaboration with the orthopaedic surgeon, Dr Norman Royle, and through countless experiments attempted to treat spastic paralysis by performing sympathetic ramisection procedures initially on goats and later on humans too (14). From his newfound knowledge overseas, Hunter and Royle postulated the dual innervation of striated muscle. Specifically, they argued that skeletal muscle fibres that received somatic innervation were involved in voluntary movement, but that the same muscles would also receive a second sympathetic innervation that would maintain a plastic tonus and would aid in supporting posture (15).

They further extended this hypothesis, postulating that this plastic tonus played an important role in poliomyelitis, myasthaenia gravis, myotonia atrophica and spastic paralysis. Hunter believed that spastic paralysis was a pathological manifestation of the plastic tonus controlled by sympathetic innervation, and as such, he and Royle believed that a sympathetic ramisection could effectively treat this condition. Furthermore, due to this dual innervation, a sympathetic ramisection would have no adverse effect upon voluntary movement, as the somatic muscle innervation would remain unaffected (16-18). Royle actually performed this procedure on more than 80 pa- 
tients, many of which are said to have had a good clinical response to the treatment.

At the time, Hunter and Royle's research garnered much interest from around the world, and in 1924 they travelled to New York where they delivered the John B. Murphy oration after being invited by the American College of Surgeons. The oration was very well received, and after demonstrating film of the outcomes from the sympathetic ramisection, some 2,500 surgeons in attendance broke into spontaneous applause (1). They were also invited to lecture at Harvard, Philadelphia, Chicago, Montreal and Toronto. While in Chicago, he received an invitation from Grafton Elliot Smith to lecture in London, which he promptly accepted (1). After delivery of his lectures in London, he travelled to Cambridge, where he spent some time with his close friend and mentor Wilson, however upon returning to London, he fell ill, and was admitted to hospital.

\section{Death and Posthumous Events}

Hunter was admitted to University College Hospital and diagnosed with typhoid fever. It is believed that he became infected during his time in the United States. He had strongly positive serological investigations that confirmed the diagnosis, and he died a few days later on December 10, 1924, as a result of cardiac failure. During his final few days, Wilson remained by his bedside the entire time. News of his death reached Australia the following day (1).

There was controversy surrounding Hunter's death, with the exact cause being debated by many medical professionals back in Australia. There were a number of reasons for this. Firstly, the fact that Norman Royle returned from overseas also being unwell, and later developing Parkinson's disease lead many to consider that perhaps both he and Hunter had encephalitis, not typhoid fever. Secondly, typhoid was seen as a socially unacceptable condition at this point in history, and many did not want to accept that one as brilliant as John Hunter could have succumbed to such a deplorable condition. Ultimately however, the medical team caring for Hunter when he died was unanimous in their diagnosis of typhoid fever, and along with his strongly positive serology, there can be little argument as to what his cause of death was. Hunter was survived by his wife, Hazel McPherson, a nurse from Royal Prince Alfred Hospital. The two had become engaged upon his return from Europe in 1923 and were married in 1924. Hazel gave birth to a posthumous son, Irvine John Hunter, in September of 1925 (1). It was Hunter's son who would establish and fund the John Irvine Hunter Memorial Lecture series, carried out under the auspices of the University of Newcastle, Australia. John Irvine Hunter Jr. noted, "I feel that series is a suitable means of remembering him because it epithomizes what he was striving for - excellence in education and research" (19).

While Hunter's work on dual innervation had been highly ambitious and well received during his tour of Europe and the United States, it was since disproven within around 5 years of his death. While the original hypothesis has been disproven, the potential that Hunter demonstrated is undeniable. It is important to remember Hunter also for the wonderful teacher that he was, who was loved by students and colleagues universally. As a researcher and anatomist, he was excellent. Wise beyond his years, and he proposed complex, thought-challenging ideas that ultimately benefited the field of anatomy.

Many have wondered just what Hunter may have been able to offer if he had not succumbed to illness. Perhaps his early demise is one of the reasons that the "Hunter Legend" lives on to this day. Grafton Elliot Smith, in his obituary for Hunter stated, "Had he lived, he might have become the foremost man of science of this age" (3). The world will never know what Hunter may have achieved, but even in his short life he has left a lasting footprint and will forever be known as one of the truly great anatomists and teachers of his time.

\section{Conclusion}

In his short but rich life John Irvine Hunter managed to overcome numerous obstacles posed by 
global politics, the local economy, personal health and complex family circumstances, rising to the unprecedented academic heights very early in his career. Although the results of some of his research projects are now falsified, at the time when they were presented, they constituted big steps towards understanding the phenomena studied. Hunter's teaching skills and ability to translate complex medical concepts to a language understandable to undergraduate students were extraordinary and he still stands as one of Australia's most remarkable medical teachers. Hunter, his life and work, remain an inspiration for generations of medical students, educators and anatomists.

Acknowledgements: We thank Ms Karen Brennan of the University of Sydney Archives for her assistance and the permission to publish John Irvine Hunter's 1920 photograph (image number G3_224_0515).

Authors' Contributions: Conception and design: GŠ; Acquisition, analysis and interpretation of data: SB and GŠ; Drafting the article: SB; Revising it critically for important intellectual content: SB and GŠ; Approved final version of the manuscript: SB and GŠ.

Conflict of Interest: The authors declare that they have no conflict of interest.

\section{References}

1. Blunt MJ. The Hunter legend: John Irvine Hunter of the Sydney Medical School 1898-1924. Sydney: Sydney University Press; 1985.

2 Brett J. Johnny Hunter: genius of singular simplicity and charm. Albury: The Albury High School Parents and Citizens Association; 1983.

3. Smith GE. Obituary. John Irvine Hunter, M. D. BMJ. 1924;2(3338):1181-3.
4. Wilson. In memoriam: John Irvine Hunter, M.D. J Anat. 1925;59:340-4.

5. Hunter JI. Abdominal pain and its associated reflex phenomena. Med J Aust. 1920;2(6-7):115-22, 143-8.

6. Morison P. Wilson, J.T. (1861-1945). In: Australian Dictionary of Biography. Canbera: National Centre of Biography, Australian National University; 2006. [cited 2020 Feb. 21]. Available form: http://abn.anu.au/biography/ wilson-james-thomas-9140/text16127.

7. Smith GE, Hunter JI. Reconstruction of the Piltdown skull. J Anat. 1925;59:27.

8. Weiner JS. The Piltdown forgery. Oxford: Oxford University Press; 1955.

9. Dawson WR, editor. Sir Grafton Elliot Smith: a biographical record by his colleagues. London: Jonathan Cape; 1938.

10. Jones RL. "No interest in human anatomy as such": Frederic Wood Jones dissects anatomical investigation in the United States in the 1920s. Endeavour. 2014;38(1):35-42.

11. Štrkalj G, Tobias PV. Raymond Dart as a pioneering primatologist. Homo. 2008;59(4):271-86.

12. Drozdov I, Modlin IM, Kidd M, Goloubinov VV. From Leningrad to London: The saga of Kulchitsky and the legacy of the enterochromaffin cells. Neuroendrocrinology. 2009;89:109-20.

13. Hunter JI. The Forebrain of Apteryx australis. Proceedings of Koninklijke Akademie Van Wetenschappen. 1923;26(1-2):807-24.

14. Hunter JI, Royle ND. The symptomatology of complete lesions of the spinal cord: an experimental study. Aust J Exp Biol Med Sci. 1924;1:57-72.

15. Hunter JI. The postural influence of the sympathetic nervous system. Med Journal of Aust. 1924;1(4):86-9.

16. Hunter JI. Lectures on the sympathetic innervation of striated muscle. BMJ. 1925;1(3344):197-201.

17. Hunter JI. Lectures on the sympathetic innervation of striated muscle. BMJ. 1925;1(3345):251-6.

18. Hunter JI. Lectures on the sympathetic innervation of striated muscle. BMJ. 1925;1(3346):298-301.

19. Hunter New E Health Libraries. John Irvine Hunter Memorial Lecture; 2015. [cited 2020 Feb. 28]. Available from: http://www.hnehealthlibraries.com.au/426. 